December 29, 2021 [Vol. 32(4)]

P-ISSN: 1680-8738; E-ISSN: 2663-547X

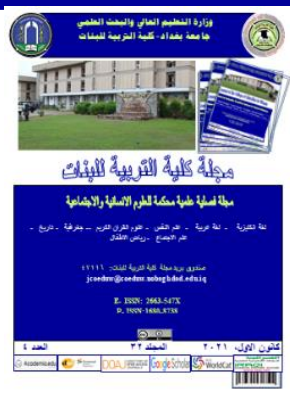

هبلة كلية الثربية لابنات

هبلة فملية عامية همكمة في الملوم الانسانية والاجتماعية تمدرها كلية الثزبية للبنات-

بامعة بغداد-|لمعراق

Journal of the College of Education for Women

A Refereed Scientific Quarterly Journal for Human and Social Sciences Issued by the College of Education for Women-University of Baghdad-IRAQ

Received: July 29, 2021

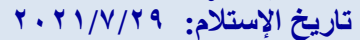

Accepted: August 25, 2021

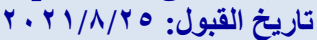

Published: December 29, 2021

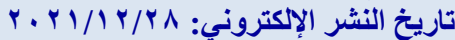

DOI: https://doi.org/10.36231/coedw.v32i4.1547

(c) (7)

\section{A Speech Acts Analysis of English COVID-19 News Headlines}

\section{Mothana N. H. Almarsomi ${ }^{1}$ and Juma'a Q. Hussein ${ }^{2}$ Department of English, College of Education for Humanities, University of Anbar ${ }^{1 \& 2}$ mot19h1023@uoanbar.edu.iq1 jumaqadir@yahoo.com²}

\section{Abstract}

News headlines are key elements in spreading news. They are unique texts written in a special language which enables readers understand the overall nature and importance of the topic. However, this special language causes difficulty for readers in understanding the headline. To illuminate this difficulty, it is argued that a pragmatic analysis from a speech act theory perspective is a plausible tool for a headline analysis. The main objective of the study is to pragmatically analyze the most frequently employed types of speech acts in the news headlines covering COVID-19 in Aljazeera English website. To this end, Bach and Harnish's (1979) Taxonomy of Speech Acts has been adopted to analyze the data. Thirty headlines have been collected from Aljazeera English news website. The findings have shown that constatives and directives occur more frequently than commissives. Other types, like acknowledgments, effectives and verdictives are not employed. The study has concluded that to pay a special emphasis on COVID-19 as an issue that preoccupied and endangered the world, headline writers of Aljazeera website uses specific speech acts, constatives and directives, more frequently than others. This makes it clear that using specific speech acts in writing headlines is an effective way for inspiring readers to easily understand the intended message.

Keywords: communicative illocutionary acts, conventional illocutionary acts, COVID-19, Speech acts, news headlines

$$
\begin{aligned}
& \text { دراسة افعال الكلام في العناوين الإخبارية الإنجليزية } \\
& \text { عن كوفيد- } 19
\end{aligned}
$$

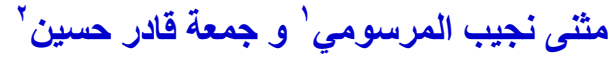

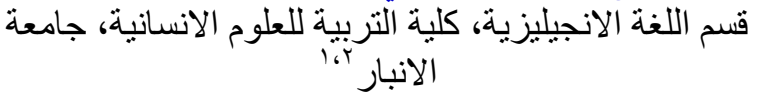

$$
\begin{aligned}
& \text { mot19h1023@uoanbar.edu.iq }{ }^{1} \\
& \text { jumaqadir@yahoo.com }{ }^{2}
\end{aligned}
$$

تعد العناوين الإخبارية العامل الاساسي في اشاعة الخبر حيث تساعد الاعبد

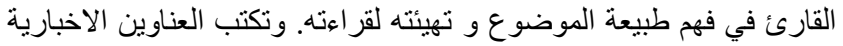

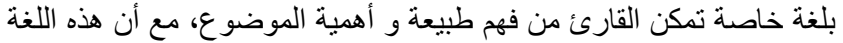

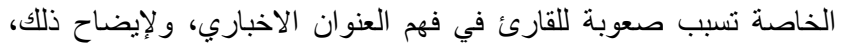

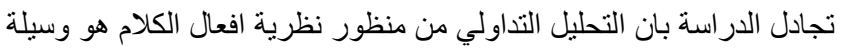

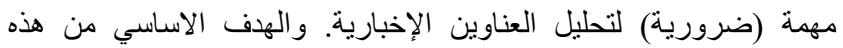

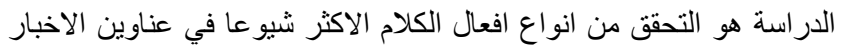

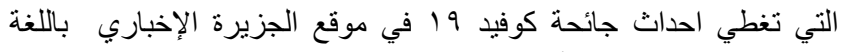

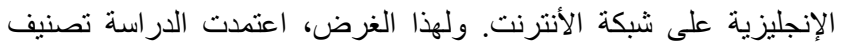

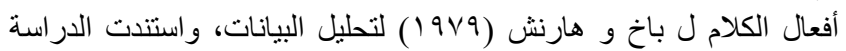

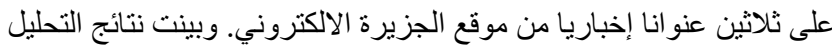

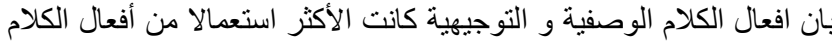

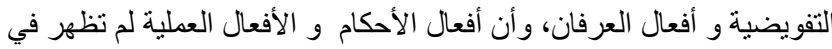

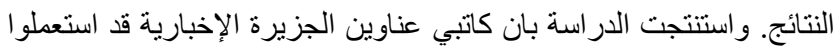

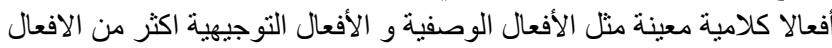

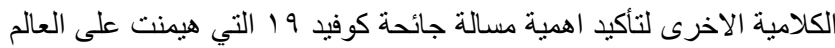

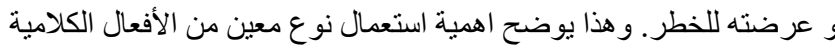

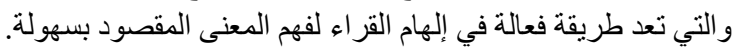

الكلمات المفتاحية: أفعال الكلام، جائحة كوفيد- 9 (ا، العناوين الإخبارية، قوة أفعال الكلام التقليدية، قوة

$$
\text { أفعال الكلام التواصلية ألوة أفيال }
$$




\section{Introduction}

The first case of COVID-19 reported in Wuhan-China on December 19, 2019 will be remembered as a critical period in the World history. Since that date the world has been facing many problems at social, health, economic, and political levels. These issues have received considerable attention from media, including media internet Websites, where Aljazeera English is no exception. Aljazeera, on line with all channels, showed the due importance and coverage to all COVID-19 related issues and events taken place worldwide. Aljazeera has loaded all pandemic related news. This means that all media resources are updating people about the pandemic. In reporting news, for example, particularly news headlines, headline writers should create and manipulate words to achieve specific purposes, as headlines have a significant role in attracting readers' attention to a topic. As the pandemic of COVID-19 spread, mass media has played a role in revealing the danger of the pandemic (Hammad and Hussein, 2021). As a form of media, news headlines are an effective way of attracting people's attention in order to take the danger of COVIC-19 seriously and to be more careful of their health.

Headlines are considered a particular type of language. This type of language shows a special style which is different from ordinary language. The main function of headlines, as stated by Van Dijk (1988), is to show the main theme of a text and summarizes its most significant information.

Accordingly, in order to better understand headlines about the pandemic, pragmatics is seen as a powerful tool for this purpose. Pragmatics reveals the writer's intention, as it is sometimes hidden and cannot be easily recognized by readers. Mey (2001) asserted that pragmatics is the study of how people use their language to communicate, and how they affect language use. More specifically, recognizing the speech act types could assist readers in understanding what the writer implicitly expresses by identifying the type of speech acts used. It has been assumed that speech acts are an aspect of communication activities.

News headlines have been explored adequately from a pragmatic aspect, including speech act theory. Headlines are also presented with abbreviated forms of syntax by the instructors of linguistics (Younus, 2019), AlHindawi (2012), and Saedi and Jabber (2020) to name but few. Al-Handawi conducted a pragmatic study that focused on finding the types of speech acts used in CNN and BBC News Headlines about the Syrian conflict. Al-Saedi and Jabber (2020) explored the pragmatic elements of newspaper headlines used in media debates. The headlines could be used to lead a world public opinion. The choice of speech act used by news writers would be interesting to have further discussion and analysis using a pragmatic point of view. Accordingly, this study distinguishes itself to deal with new data on the pandemic of COVID-19 headlines that have not yet been addressed adequately. The use of speech act theory in headline analysis allows not only the investigation of word meanings and linguistic systems, but also the examination of linguistic structures utilized to express speech acts. In this vein, Hummadi, Al-Bahrani, \& Al-Saadi (2015) maintained that one of the fascinating subjects in speech acts theory is how words can be employed not just to provide information, but rather to perform actions. Accordingly, this study will adopt speech acts theory as a theoretical formwork, specifically that of Bach and Harnish's (1979) clarification of speech acts as a model for pragmatically analyzing the most frequently employed types of speech acts in COVID-19 news headlines in Aljazeera English news website. Therefore, the study is to answer the following research question: What are the types of speech acts most frequently employed in Aljazeera English COVID-19-based news headlines?

This study is significant for researchers in linguistics in general and pragmatics in particular, since it corroborates pragmatics as a tool in analyzing the intended meaning of news 
headlines. It also gives them full understanding of the types of speech acts and how to deal with them in such a work.

\section{Theoretical Framework}

\subsection{News Headlines}

A headline is defined in the Glossary of Newspaper Terms (n.d.) as "an explanatory title over a newspaper article summarizing the main point for the reader". Swan (2005) stated that "headlines are the short titles above news reports (e.g., Dog Finds Roman TREASURE). English news headlines can be very difficult to understand. One reason for this is that headlines are often written in a special style" (p. 292). This is because headlines must transmit a large quantity of information in the smallest period of time; they have distinct styles from standard sentences (Yoshimi, 2001). In Reah's (2002) words, a headline is an exclusive type of texts. It has a number of functions that determines its forms, contents and structures specifically. It shows the complete article in a limited number of words, drives the reader mostly to the news, and encourages the reader to the article if it appears from the front page.

Headlines are a limited gateway to a broader subject. They are put at the top of the large, bold kind of news articles (Le, 2012). This statement agrees with Azziz and Rasheed, who stressed the importance of a headline length (as cited in Azziz, 2013). In this context, Ismail (2016) mentioned that there have been several assumptions as to what the function of a headlines is. One of them is the simple point that a room is preserved by headlines. This makes a common sense for the printed newspaper, considering the right special limits of the newspaper, that the headline needs to express as many details as possible in few words.

Duanprakhon (2012) declared that "news is a word that is relatively difficult to define" (p. 8). Further, Develotte and Rechniewski (2001), Claude (1980) noted that newspaper headlines not only place the information in a word, but also provide hints to how the implied messages can be decoded. Understanding the unity of the presupposed and a viewpoint details helps the reader to adequately understand social and cultural references. Galperin (1977) displayed that headlines are parts of an entire story on the details of the news article. According to Chiluwa (2009), headlines are pieces of speech that seem to be investigated as independent texts. Headlines are the actual parts of news reports with meanings that are pragmatically encoded, aside from only supplying information about the news. Such meanings are socially interpretable. Headlines have social roles, too. If the concept of pragmatics is applied as a social context analysis, then headlines may be viewed as having illocutionary functions as speech acts. Reah (2002) noted that a headline is a "unique type of a text that consists of a range of functions that specifically dictate its shape, content and structure"(p.13). Mårdh (1980) mentioned that a determinative and unambiguous meaning of the word 'headline' is difficult to provide, and it appears to be used intuitively, even in linguistic research. Bell (1991) considered a headline as "an abstract of an abstract" in that it presents the narrative at a higher level (p.150). Headlines play an important part in the transmission of news. Taiwo (2007), for instance, highlighted the significance of headlines by stating that they are accustomed to "initiate, sustain and shape discourse on the views of readers"(p. 244).

The headline language is frequently identified as a "block Language" that exists typically in titles, labels, advertisements, newspapers, and websites (Quirk, Greenbaum, Leech, \& Svartvik, 1985). As a consequence, "non-sentences" are the most evident type of a block language; they include the noun/ noun phrase and an independent "nominal clause". The use of the present simple verb tense, rather than present perfect, is another particular feature that occurs in most news headlines. Additionally, in order to express the future or a predictable arrangement of an event, there is a traditional use of "to". As well, "asyndeton" is used when conjunctions are omitted. In general, they are used intransitively instead of being transitive, 
referring back to verbs; however, this shape may cause ambiguity. In general, it is important to concentrate on a headline that can be analyzed in terms of a "clause structure," and more on certain forms of SV, SVA, SACs, or SVOdCo (Quirk et al., 2010).

The headline language is more like most expressions uttered. Journalists manipulate words to execute a specific action that activates the attention of the reader to read the full report (Waugh, 1995).The meaning of headlines has semantic, pragmatic, syntactic and lexical characteristics of its own. In this sense, speech acts are the key units of a linguistic communication of this kind. Besides, classifying speech acts throughout newspaper headlines allows readers to understand the message that reporters attempt to express, such as swearing, commanding, questioning, promising, and thanking. That is, the theory of the speech act provides a way to best interpret the message throughout the headline (Abba, Olakunle, \& Musa, 2015).

In a few words, interpreting headlines using the theory of speech acts not only makes it possible to analyze the sense of words as well as syntactic structures, but also helps to analyze their intention, such as warnings, agreements, challenges, commands, promises. A typical headline describes the meaning of a difficult news article; it quickly and accurately informs and draws readers' interests.

\subsection{Speech Act of the Headlines}

Language is a way of communicating meaning and executing an event, whether spoken or written. Language encourages individuals to express their ideas, feelings, emotions and expectations (Wierzbicka, 1992). Searle (1965) explained how people employ language to accomplish an act: "speaking language is performing speech acts, such as making statements, giving commands, asking questions, making promises" (p.16). People perform such tasks by using a language. The most exciting part of a promise is the responsibility that this act lays on the speaker, as speakers believe that they must now fulfill their promise (Al-Jawadi \& AbdulMajeed, 2007). The intention of the sentence is expressed by functions. Sentences are classified into four categories with respect to the function criterion: (statements, questions, commands and exclamations). Headline manufacturers coin headlines depending on the purpose of the sentences in order to express their specific and concise information, according to functional categorizations of sentences (Metz, 2005). Headlines should then be listed as follows:

\subsubsection{Headlines of Statement}

A statement is a sentence which its primary purpose is to transmit knowledge. It involves a topic preceded by a verb (Quirk et al., 1985). A statement sentence has a declarative framework, which is used to declare a known thing (Crustal, 2011). In headlines, a modality statement is widely used when the primary purpose in headlines is to transmit information.

\subsubsection{Headlines for Questions}

Questions are extremely strong and have a significant impact on the brain because they stimulate people's interest. The sudden appearance of a question mark stimulates their brain; however, since one already understands what s/he will get from just a headline, his/her imagination may be stifled before it even begins. The best quality question headlines are those that ask a question that the reader can understand and empathize with, connect to, or want to know the answer to (Seiter, 2014).

Shams (2002) explained question headlines in a form of a question as a declaration sentence. This approach encourages the reader to consider the proposed solution, and to try to comprehend the answer. Sentence questions are sentences with only a question word (wh-) at the start of a sentence; a question mark is only at end of a sentence, or when there is a subject and verb inversion.

\subsubsection{Headlines for Commanding}

Directive speech acts seem to be the command headlines. They display the intention of the speaker to convince the receiver to act in a certain way. A command sentence is 
linguistically characterized by, as Crystal (2011) stated, "a sentence which typically has no subject and where the verb is in the imperative mood" (p.83). Its primary role is to guide somebody to do something. Command headlines will be used as instructions or suggestions to persuade the reader to do something or to stop it. Shams (2002) identified command headlines as a specific type of headlines that clearly tells the reader about the core subject of the news. They are considered popular and generally easy to understand.

\subsubsection{Headlines for Exclamation}

Crystal (2011) explained that exclamation sentences typically reflect the feeling of the speakers or their emotions. They should lack linguistic features and point to the exclamation mark with a heavy intonation. Sometimes, they can be used as a minor statement. Exclamatory headlines are symbolic acts of speech when they represent the speaker's psychological state. This modality can be used by headline writers to expose their thoughts or attitudes. The interaction between the speech act as well as the role of a whole headline seems obvious after reading the speech act and any headline (Gibbs \& Gibbs, 1999). This is in line with Searle's (1968) view that "often we mean more than we actually say"; journalists build headlines and mean beyond what they speak (p.415).

In publishing headlines, the use of a language pragmatically plays a major role as pragmatics is an implied interpretation or "invisible meaning" with very few terms representing the writer's illocutionary force, including his orientations. The correspondence between a writer and reader can sometimes be recognized within pragmatics, speech acts, just like headlines, and can serve particular problems and perform a multitude of speech acts, such as (promising, asserting, declaring, urging, warning, and informing) (Iarovici \& Amel, 1989, as cited in Dor, 2003).

\subsection{The Model of Analysis}

The theory of speech act was formulated firstly by John Austin in 1962. In his best-known work on the functions of language, "How to do Things with Words", Austin classified illocutionary acts into five types (Verdictives, Exercitives, Commissives, Expositives, and Behabitives). Searle (1975) criticized Austin's taxonomy of illocutionary acts as they are overlapped and often contain items that are not consistent with his category description. $\mathrm{He}$ proposed his classification of speech acts, which he called illocutionary acts, consisting primarily of five types: (a) representatives (or assertives), (b) directives, (c) commissives, (d) expressives, and (e) declarations.

The study adopted Bach and Harnish's (1979) model of speech acts classification. Bach and Harnish (1979) differentiated six general types of speech acts on the basis of the psychological condition of the speaker that they call the "attitude" of the speaker. Generally, speech acts, according to Bach and Harnish, are of two broad types: conventional and communicative. Conventional speech acts are subdivided into two categories: verdictives and effectives. Communicative speech acts are further subdivided into four main categories: constatives, directives, commissives and acknowledgments. They are briefly explained as follows:

\section{Constatives}

Bach and Harnish (1979) stated that "in general, constatives are the expression of a belief, together with the expression of an intention that the hearer forms, or continues to hold, a similar belief. Simple assertives, descriptives, and ascriptives are of this sort" (p.44). The perlocutionary purpose that typically follows these acts seems to be that the hearer/reader thinks of the proposition in question, or proceeds to believe it, possibly by pretending that such a speaker believes it.

Constatives express the opinion of the speaker and his purpose or wish for the hearer/reader to have or shape a related belief. The following fifteen subtypes contain them: (assertives, predictives, retrodictives, descriptives, ascriptives, informatives, 
confirmatives, concessives, retractives, assentives, dissentives, disputatives, responsives, suggestives and suppositives) (p.42). The following example quoted in Huang (2016) illustrates this type:

\section{a. "The soldiers are struggling on through the snow" (p.133).}

\section{Directives}

Bach and Harnish (1979) mentioned that "directives express the speaker's attitude toward some prospective action by the hearer/reader. If this were all they expressed, they would be merely constatives with a restriction on the propositional content (namely, that a prospective action be ascribed to the hearer)" (p.47). Directives also convey the intention of the speaker (desire, wish) that his or her speech or attitude be taken as a justification used for the action of the hearer/reader. Instead of using the term "exercitive" from Austin, which seems rather limited in scope, Bach and Harnish (1979) adapted the term "directive" from Searle, saying that "it is .. conveniently vague, being broad enough to cover the six kinds of acts that belong in this category" (p.47). Directives are exemplified by Huang (2016) as follows:

b. "Could you please get that lid off for me?" (p.133).

\section{Commissives}

Bach and Harnish (1979) asserted that "commissives are acts of obligating oneself or of proposing to obligate oneself to do something specified in the propositional content, which may also specify conditions under which the deed is to be done or does not have to be done" (p.50). Huang (2016) illustrated commissives in the following example:

\section{c. "I'll be back in five minutes" (p.134) \\ 4. Acknowledgements}

Bach and Harnish (1979) explained that "acknowledgments are the central cases of Austin's motley class of 'behabitives'. They express, perfunctorily if not genuinely, certain feelings towards the hearer/reader. These feelings and their expression are appropriate to particular sorts of occasions" (pp.51-55).

\section{Effectives}

Bach and Harnish (1979) stated that these conventional speech acts impact a change throughout the state for institutional affairs. For example,

d. "a student is graduated and a bill is voted". They added that "verbs denoting effective acts are: resign, vote, and bequeath, etc." (pp. 110111).

\section{Verdictives}

Bach and Harnish (1979) explained that "verdictives are judgments that by convention have official, binding import in the context of the institution in which they occur" (p. 111). For instance, calling a player out, finding the defendant guilty and evaluating a piece of property are all verdictives. All of these acts offer an umpire, a judge or a tax inspector the attendant power. Figure 1 summarizes Bach and Harnish's classification of speech acts. 


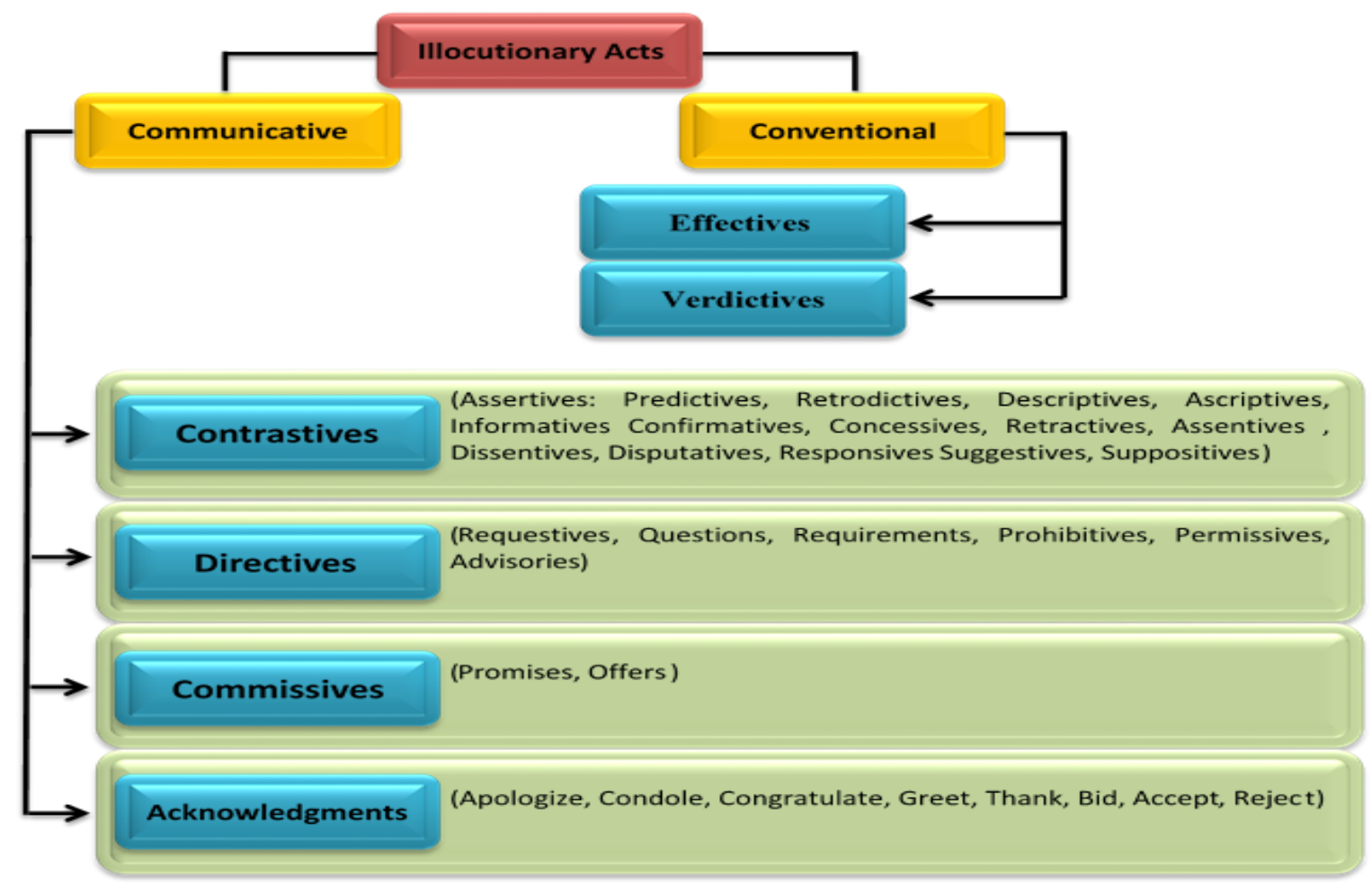

Figure 1

Bach and Harnish's (1979) Classification of Communicative and Conventional Illocutionary Act

\section{Methodology}

This study investigates the pragmatics of selected English COVID-19 News Headlines. In particular, it investigates the most frequent types of speech acts employed in the news headlines covering COVID-19. A qualitative as well as a quantifying descriptive analysis methods have been used based on Bach and Harnish's (1979) classification of speech acts. The data of this study have been collected randomly from Aljazeera English website news headlines for a period of four months extending from October 1, 2020 up to February 1, 2021. For the purpose of analysis, 30 news headlines have been selected.

\subsection{Data Analysis and Findings Discussion}

To achieve the objective of this study, which reads: pragmatically analyzing the most frequently employed types of speech acts in the news headlines covering COVID-19 in Aljazeera English website, the researchers have adopted Bach and Harnish's (1979) classification. The classification involves the main categories and subcategories of speech acts as shown in the following paragraphs:-

\subsubsection{Classification of the Main Types of Speech Acts in Headlines}

Bach and Harnish's classification involves six main categories: constatives, directives, commissives, acknowledgements, effectives, and verdictives. The frequency and percentage of each type used in headlines are shown in Table 1. 
Table 1

Classification of Headlines into Main Speech Acts

\begin{tabular}{llll}
\hline Headlines & Illocutionary point & Number & $\%$ \\
\hline HL 1 to HL 18 & Constatives & 18 & $60 \%$ \\
\hline HL 19 to HL 28 & Directives & 10 & $33.33 \%$ \\
HL 29 to HL 30 & Commissives & 2 & $6.66 \%$ \\
HL 0 to HL 0 & Acknowledgments & 0 & $0 \%$ \\
HL 0 to HL 0 & Effectives & 0 & $0 \%$ \\
HL 0 to HL 0 & Verdictives & 0 & $0 \%$ \\
\hline Total & & 30 & $100 \%$ \\
\hline
\end{tabular}

Table 1 shows that only three types of illocutionary acts were used in headlines with different percentages. Constatives scored first with $60 \%$ percentage, directives scored second with $33.33 \%$ percentage, and commissives were of $6.66 \%$ percentage. Other types like acknowledgements, effectives, and verdictives, were not employed. Their percentages were $0 \%$. Finding the illocutionary point seems to be useful for determining news headlines; it indicates the relationship between content and context. The high frequency of constatives occurrence was supported by the findings of the previous studies by Rustam (2013), and Qomariyah (2019). According to their findings, representatives were the most frequent illocutionary acts in texts, particularly in news headlines. On the other hand, the low percentage of Commissives, Acknowledgements, Effectives and Verdictives coincides with these studies. The similarities found among the results of the previous studies indicates that such acts are rarely used in texts, particularly headlines.

\subsubsection{Classification of Sub-Types of Speech Acts in Headlines}

The main types proposed by Bach and Harnish (1979) include many sub-types. Such an analysis involves tabulating the frequency of occurrences as shown in details in the following paragraphs:

\section{Constatives:}

There are fifteen subtypes of constatives, based on Bach and Harnish (1979): "(assertives, predictives, retrodictives, descriptives, ascriptives, informatives, confirmatives, concessives, retractives, assentives, dissentives, disputatives, responsives, suggestives and suppositives)" (p.42). There are specific verbs associated with each sub-type. As shown in Table 1, constatives have been used 18 times. However, only three subtypes of constatives have been found here: assertives, confirmatives, and concessives; consider Table 2. The highest frequency of the sub-types were Asssertives (77.77\%), Confirmatives (16.66\%), and Concessives $(5.55 \%)$. The rest of other sub-types were all $0 \%$. 
Table 2

Subtypes of Constatives in Headlines

\begin{tabular}{|c|c|c|c|c|}
\hline Constatives & & & & \\
\hline Subtypes & Headlines & $\begin{array}{l}\text { Verbes associted with } \\
\text { this act }\end{array}$ & Number & $\%$ \\
\hline Assertives & HL 1 to HL 14 & $\begin{array}{l}\text { say, declare, claim, } \\
\text { deny }\end{array}$ & 14 & $77.77 \%$ \\
\hline Predictives & (Not used) & (None found) & $\mathbf{0}$ & $0 \%$ \\
\hline Retrodictives & (Not used) & (None found) & $\mathbf{0}$ & $0 \%$ \\
\hline Descriptives & (Not used) & (None found) & $\mathbf{0}$ & $0 \%$ \\
\hline Ascriptives & (Not used) & (None found) & $\mathbf{0}$ & $0 \%$ \\
\hline Informatives & (Not used) & (None found) & $\mathbf{0}$ & $0 \%$ \\
\hline Confirmatives & HL 15 to HL 17 & confirm, find & 3 & $16.66 \%$ \\
\hline Concessives & HL 18 to HL 18 & admit & 1 & $5.55 \%$ \\
\hline Retractives & (Not used) & (None found) & $\mathbf{0}$ & $0 \%$ \\
\hline Assentives & (Not used) & (None found) & $\mathbf{0}$ & $0 \%$ \\
\hline Dissentives & (Not used) & (None found) & $\mathbf{0}$ & $0 \%$ \\
\hline Disputatives & (Not used) & (None found) & $\mathbf{0}$ & $0 \%$ \\
\hline Responsives & (Not used) & (None found) & $\mathbf{0}$ & $0 \%$ \\
\hline Suggestives & (Not used) & (None found) & $\mathbf{0}$ & $0 \%$ \\
\hline Suppositives & (Not used) & (None found) & $\mathbf{0}$ & 0\% \\
\hline Totle 15 & HL 18 & & 18 & $100 \%$ \\
\hline
\end{tabular}

\section{a. Assertives}

The verbs associated with assertives according to Bach and Harnish (1979) are (affirm, allege, assert, aver, avow, claim, declare, deny, indicate maintain, propound, say, state, and submit). However, only the verbs (say, declare, claim, deny) have been invested in the selected headlines. Table 2 shows that constatives have been frequented 18 times. Assertives as a subtype occurred 14 times. The high score connotes the headline writers' intension to persuade reader/hearer about something. Some examples of this subcategory can be seen in (HL1), "Spain declares state of emergency to stem soaring COVID-19 cases", and (HL6.), "WHO says 'too early to ease' virus curbs in Europe"; both headlines express truth-value, which means they can be checked to see whether it is true or not. In (HL6), WHO describes the truth that COVID-19 pandemic may take a longer time to get rid of. In (HL1), Spain confesses that COVID-19 pandemic has spread significantly, so, Spain declared the emergency.

\section{b. Confirmatives}

According to Bach and Harnish (1979), the verbs (appraise, evaluate, bear testimony, certify, infer, prove, corroborate, diagnose, discover, judge, substantiate, testify, validate, check, vouch for) are classified as confirmatives. The findings showed that the sub-category 'confirmatives' appeared three times. Only two 
verbs (confirm and find) were used in COVID-19 headlines. The verb 'confirm' (HL15, HL17) was used to highlight that the stories of infections of COVID-19 cases were based on the facts. The headline (15) shows that France and Lebanon confirm new cases of Corona virus depending on the report on passengers coming from the United Kingdom. Besides, (HL 17) explains South Korea's confirmation of injuries and an outbreak of COVID-19 that started in March in the army camps; this is why it announced attendance on flights.

\section{c. Concessives}

Concessives express a belief in contrast to what the speaker would like to believe. Bach and Harnish (1979) presented the verbs (acknowledge, admit, agree, allow, assent, concede, concur, confess, grant, own) as concessives. The subcategory 'concessives' occurred once in the data. According to the findings, the verb (admit) was used in the data to show that:

in uttering expression, speaker concedes that proposition if speaker expresses i. the belief that proposition, contrary to what he would like to believe or contrary to what he previously believed or avowed, and ii. the intention that reader believe that proposition. (p.43)

Therefore, this verb expresses that a speaker concedes the proposition if he expresses his belief in it, even if it is contrary to his intentions. The HL18, "Russia admits COVID death toll third-worst in the world", expresses truth-value, which means it can be checked to see whether it is true or not. This means Russia concedes that COVID-19 death count is the third highest in the country.

\section{Directives}

As mentioned before, this type expresses the attitude of the speaker towards an action presented by the hearer. It involves six subtypes of acts "Requestives, Questions, Requirements, Prohibitives, Permissives, and Advisories" (pp.47-48). Each of these subtypes has its own set of verbs associated with it. In the findings, directives appeared ten times, and were ranked second to constatives. According to data analysis, directive verbs were only expressed in three subtypes (Requestives, Requirements, and Advisories), as shown in Table 3.

\section{Table 1}

\section{Subtypes of Directives in Headlines}

\begin{tabular}{|c|c|c|c|c|}
\hline \multicolumn{5}{|l|}{ Directives } \\
\hline Subtypes & Headlines & $\begin{array}{l}\text { Verbes associted } \\
\text { with this act }\end{array}$ & Number & $\%$ \\
\hline Requestives & HL 26 to HL 26 & invite & 1 & $10 \%$ \\
\hline Questions & (Not used) & (None found) & $\mathbf{0}$ & $0 \%$ \\
\hline Requirements & HL 27 to HL 28 & order & 2 & $20 \%$ \\
\hline Prohibitives & (Not used) & (None found) & $\mathbf{0}$ & $0 \%$ \\
\hline Permissives & (Not used) & (None found) & $\mathbf{0}$ & $0 \%$ \\
\hline Advisories & HL 19 to HL 25 & warn, urge & 7 & $70 \%$ \\
\hline Totle & HL 10 & & 10 & $100 \%$ \\
\hline
\end{tabular}

\section{a. Requestives}

Bach and Harnish (1979) put the verbs (ask, beg, beseech, implore, insist, invite, petition, plead, pray, request, solicit, summon, supplicate, tell, urge) under Requestives. The sub-category 'Requestives' occurred only once in the data; only the verb (invite) was used in COVID-19 headlines to show that "in uttering expression, 
speaker requests hearer to actions if speaker expresses: (i.) the desire that hearer do action, and (ii.) the intention that hearer do action because (at least partly) of speaker's desire" (p.47). This verb appeared in HL26, "Taiwan not invited to WHO meeting despite COVID-19 success. Lobbying for participation as observer unsuccessful despite island's success in preventing disease's spread". This headline indicates the speaker's intent or feeling to persuade the reader to do something. The verb "invite" conveys a sense of seriousness or urgency. Some requesting verbs have a very limited scope. The verb "invite," for example, refers to invitations for the presence of the hearer or reader.

\section{b. Requirements}

Bach and Harnish (1979) asserted that "requirements, such as ordering or dictating, should not be confused with requests, even strong ones" (p.48). They explained the difference, saying that in request, the speaker intends the reader to accept the former's expressed wish as an excuse to act. In requirements, the speaker's conveyed purpose is for the reader to consider the speaker's utterance as a reason to intervene, since it is a difficult reason to act. In the data, the sub-category, "requirements", appeared twice. Further, the verbs, (order and demand), were used in COVID19 headlines to show the speaker's authority to convey a wish for the reader to act in the way the speaker wishes. In HL27, "South Korea orders COVID-19 vaccines for 88 percent of population", and HL28, "Trump demands Congress amend 'wasteful' COVID relief bill", there shows the speakers' authority in using commands.

\section{c. Advisories}

Bach and Harnish (1979) defined "advisories" as: what the speaker expresses is not the desire that hearer do a certain action but the belief that doing it is a good idea, that it is in hearer's interest. Speaker expresses also the intention that hearer take this belief of speaker's as a reason to act. (p.49)
For example, in a warning, the speaker assumes that the reader is in danger or problem. In the data, the sub-category, "advisories", occurred seven times. Bach and Harnish (1979) put the verbs (admonish, advise, caution, counsel, propose, recommend, suggest, urge, and warn) under the label "Advisories" (p. 48). According to the findings, the verbs (urge, warn) were used in COVID-19 headlines. For example, in HL20, "WHO urges the world 'don't give up' as COVID-19 pandemic resurges", the speaker here urges the reader to take a certain action, assuming that he has good reasons for doing so. The verb 'urge' has a directive connotation. It connotes a specific course of action with a suitable mode of an execution. The assumption is that a plan of action is urgent or immediate. A speaker who urges the listener to take a certain course of action must assume that he has motives for taking that course of action. The HL21, "COVID-19 cases still surging in the Americas, WHO warns", explains that a directive illocutionary act is about a negative situation in the news that must be stopped. As a result, WHO issues a warn. Preparatory concerns have been derived from the speaker's understanding that the most likely situation will occur, and it will have a negative impact on people, and the critical events derived from the propositional material will warn readers to adverse events.

\section{Commissives}

Bach and Harnish (1979) explained that when one expresses the intention to take action and believes that one's speech commits one to take action, at least under the circumstances stated or mutually considered to be appropriate, one is committing oneself to take action. Commissive verbs work like performative verbs though commissive acts indicate the commissive purpose of a statement. Bach and Harnish (1979) distinguished two main types of commissives: promises and offers, "promises are acts of obligating oneself; offers are proposals to obligate oneself" (p.50). Every one of these subtypes has specific verbs used for speech act classification. Commissives occurred twice in the 
data, and appeared only in one subtype, Promises, as shown in Table 4.

Table 4

Subtypes of Commissives of Headlines into Speech Acts

\begin{tabular}{lcccc}
\hline Commissives & Headlines & $\begin{array}{c}\text { Verbes associted } \\
\text { with this act }\end{array}$ & Number & $\%$ \\
\hline Subtypes & HL 29 to HL 30 & promise & 2 & $100 \%$ \\
\hline Offers & (Not used) & (None found) & 0 & $0 \%$ \\
\hline Totle & HL 2 & 1 & 2 & $10 \%$ \\
\hline
\end{tabular}

\section{a. Promises}

Bach and Harnish (1979) put the verbs (promise, swear, vow) under the label of promises, representing a subtype of commissives. The sub-category 'promises' occurred twice in the data. The verb (promise) is used in COVID-19 headlines to show that

In uttering expressions, speaker promises hearer to action if speaker expresses: $i$. the belief that his utterance obligates him to action, ii. the intention to action, and iii. the intention that hearer believe that speaker's utterance obligates speaker to action and that speaker intends to action (p.50).

This verb expresses a speaker's agreement that must include the promise that he or she will take any initiative in the future. For example, HL29, "G20 leaders promise fair access to coronavirus vaccines" and HL30 "Most Canadians will get COVID-19 vaccine by September: Trudeau" show that there is a promise from the speaker (G20 leaders and Prime Minister Justin Trudeau) to do something in future.

\section{Acknowledgements}

Bach and Harnish (1979) stated that 'Acknowledgments' include the subcategories: condole, greet, bid, accept, thank, reject, apologize, and congratulate" (p.51). Every one of these subtypes has specific verbs used for speech act classification. According to the finding of the data, verbs of acknowledgments were not used in the data.

Since acknowledgments reflect a subjective viewpoint, they were less frequently used than the other types. The subcategories of acknowledgments indicate that the speaker attempts to use expressions that support his own purposes, and this by itself reflects subjectivity more than objectivity. Within media, subjectivity is seen as weakness. Therefore, the disappearance of subcategories, like "condole, greet, bid, accept, thank, apologize, and congratulate" indicates that the subject of COVID-19 news headlines requires an actual piece of evidence rather than merely presenting personal situations, accepting some personal matters, and thanking readers for persuading other people.

\section{Effectives}

Bach and Harnish (1979) explained that "effectives are utterances that, when issued by the right person under the right circumstances, make it the case that such and such. This is a matter not of causality but of mutual belief" ( $\mathrm{p}$. 113). The verbs "resign", "vote", and "exempt", which denote effective acts, may have different meanings. For example, resigning simply means resigning from a position; vetoing simply means negating a piece of law; and exempting simply 
means making an exception for a rule. However, effectives did not appear in the findings.

\section{Verdictives}

Bach and Harnish (1979) mentioned that the difference between effectives and verdictives is that effectives produce facts, while verdictives are just fact-based determinations. They stated that "a verdictive would be merely a constative if it had no institutional import of the sort described" (p.115). The findings have shown that verdictives did not appear in the results. That is, verdictives serve the institutional function of finding solutions in order to carry out an institutional activity, based on the circumstances. This means that the official judgments need the context of the institution.

\subsubsection{Findings and Discussion}

Basically, the dominance of certain types of speech act are usually determined by the field and the situations in which they are employed. Based on the analysis, results have shown the following:-

1. Constatives, specifically the subtype 'assertives', occupied the first place in the selected data. They constituted $77.77 \%$. This result is normal, since headlines express truth-value. This means they can be checked to see whether they are true or not.

2. Directives are ranked second; writers of headlines usually utilize directives to direct readers to the information they need. The subcategory, "advisories", appeared 70\%. Advisories have been offered as both a piece of advice (a positive proposal), and a warning (a negative proposal). This is because the topic 'COVID-19' covered by the headlines determines the importance of this type. For example, HL19, "Biden advisers urge immediate COVID-19 action as infections soar", and HL25, "Fauci warns US COVID19 outbreak may worsen after holidays", express both advice and warning, respectively.

3. "Commissive" constituted $6.66 \%$. Commissive verbs function similarly as performative verbs by indicating the commissive intention of a sentence through commissive acts. According to Bach and Harnish (1979), "promises and offers" are two types of commissives.

4. Acknowledgments constituted 0\%. These types have not been used because the major goal of headlines is usually to inform or assert something not to promise, offer, apologize, thank or congratulate.

5. Effectives and verdictives confirm a convention, that is, when the meaning of a conventional verb is unraveled, there will be utterances that help fulfill particular institutional specifications implicit in institutional terms. However, such acts have not been found in the sample, and are rarely used in headlines, since they serve the institutional role of finding solutions in order to carry out an institutional activity, depending on the conditions.

6. The data have been categorized by the act they perform: constatives, directives, commissives, acknowledgments, effectives and verdictives. The findings have indicated that "constatives" are the most common type of speech acts used, with a percentage of $(60 \%)$. The constatives category of speech acts is employed more frequently in headline writings than in any other type. This can be attributed to three reasons: The first is functional; the purpose behind using constatives is to inform. The second factor has to do with the issue of reliability. Constatives commit the author to the truth of his assertions. In this context, Bach and Harnish (1979) stated that "constative is the expression of a belief, together with the expression of an intention that the hearer form (or continue to hold) a like belief" (p.42). The validity of news is one of the criteria of success in the media world, as a result, media institutions, particularly the well-known ones, such as Aljazeera English news, are interested in presenting news as facts, in order to protect their institutions' reputations. The third factor is that 
constatives can be verified as true or false; therefore, they may be used to examine a situation. Journalists employ conclusives in headline writings to persuade the hearer of the news' reliability. The reader may determine whether the news is true or false by combining information from several sources. As a result, the constative speech act is frequently used in headlines.

7. Finally, "constatives" are the most common used type of speech acts, a result that is in line with the findings of past studies, such as Rustam (2013) and Qomariyah (2019). These studies showed that representatives (assertives) were most frequently found in the selected data. The findings have further revealed that to persuade people to believe in COVID-19 pandemic, the a "global concern", actual facts were required rather than unbelievable views and beliefs. The most important thing for the reader is to determine if anything is true or false. That is, this issue is based on facts rather than guesses.

\section{Conclusions}

Answering the research question, What are the types of speech acts most frequently employed in the Aljazeera English news headlines covering COVID-19?, the researchers have found the following:-

1. Only three categories of communicative illocutionary acts (constatives, directives, commissives) based on Bach and Harnish's (1979) taxonomy of speech acts have been employed in the selected data with varying proportions.

2. The quantifying descriptive analysis has revealed that constatives have been widely frequented than others. The data were rich in constatives illocutionary headlines, accounting for $60 \%$ percentage of the total, whereas the percentage of the directives illocutionary point reached $33.33 \%$. Other headlines were dispersed in different percentages, such as commissives, acknowledgements, effectives, and verdictives.
3. To achieve the headlines purposes, writers need to employ a minimal number of speech acts. The illocutionary acts can be recognized by the readers via using these speech acts.

4. To make it clearer and easier to understand, headline writers endeavor to use effective speech acts to reflect the illocutionary force of the topic implicated in the headline. In this sense, a pragmatic analysis from a speech act theory perspective has been a plausible tool for headline analysis in Aljazeera Web Site. That is, using specific speech acts in writing headlines is an effective way for inspiring readers to easily understand the intended message implicated in headlines.

\section{References}

Abba, T. S., Olakunle, I. A., \& Musa, N. A. (2015). A speech act analysis of daily trust newspaper headline reports on Boko Haram attacks. Journal of Communication and Culture, 6(1). Retrieved from https://fdocuments.in/reader/full/a-speechact-analysis-of-daily-trust-identifying-thetypes-of-speech-acts-used.

Al-Hindawi, F. H., \& Ali, A. H. (2018). A pragmatic study of $\mathrm{CNN}$ and $\mathrm{BBC}$ news headlines covering the Syrian conflict. Advances in Language and Literary Studies, 9(3), 43-51.

Al-Jawadi, K. H., \& Abdul-Majeed, R. K. (2007). Modification of Searle's speech act of promising in its application to selected religious and political texts. Journal of College of Education for Women, 18(1), 287-300.

Al-Saedi, H. T. J., \& Jabber, K. W. (2020). A pragmatic study of newspaper headlines in media discourse: Iraq as a case study. International Journal of Linguistics, Literature and Translation, 3(3), 48-59. 
Austin, J. L. (1962). How to do things with words: Lecture I. Massachusetts: Cambridge University Press.

Azziz, S. S. (2013). The direct of art journalism headline in the first page of Al-Sabah newspaper Al-Iraqi from (1120123112012). Journal of College of Education for Women, 24(3), 838-850.

Bach, K., \& Harnish, R. M. (1979). Linguistic communication and speech acts. Cambridge: MIT Press.

Bell, A. (1991). The language of news media. Oxford: Blackwell.

Chiluwa, I. (2009). News headlines as pragmatic strategy in Nigerian press discourse. International Journal of Language, Society and Culture, 27, 63-71.

Crystal, D. (2011). A dictionary of linguistics and phonetics. (Vol. 30). Blackwell: John Wiley \& Sons.

Develotte, C. \& Rechniewski, E. (2001). Discourse analysis of newspaper headlines: A methodological framework for research into national representations. The Web Journal of French Media Studies, 4(1), $1-12$.

Dor, D. (2003). On newspaper headlines as relevance optimizers. Journal of pragmatics, 35(5), 695-721.

Duanprakhon, P. (2012). Critical discourse analysis of news headlines: A case of youth crime in Thailand (An Unpublished Master Thesis). School of Language and Communication National Institute of Development Administration, Thailand.

Galperin, I. (1977). Stylistics: Moscow: Higher School.

Gibbs, R. W. \& Gibbs, R. W. (1999). Intentions in the experience of meaning. Cambridge: Cambridge University Press.
Glossary Newspaper Terms. (n.d.). Retrieved from

https://nieonline.com/coloradonie/do wnloads/journalism/GlossaryOfNews paperTerms.pdf

Hammad, F. M., \& Juma'a, Q. H. (2021). Persuasive strategies in WHO COVID19 virtual press conferences. Journal of the College of Education for Women, 32(2), 19-35.

Huang, Y. (2016). Pragmatics: Language use in context. In The Routledge handbook of linguistics, (pp. 221-236). Oxford: Routledge.

Hummadi, S. S., Al-Bahrani, R. H., \& Al-Saadi, S. (2015). Students' Ability to Diagnose Threat and Warning Act Clues in George Orwell's Novel "1984". International Journal of English and Education, 4(2), 365-373.

Ismail, H. (2016). Pragmatic and Semantic Potential of Newspaper Headlines. USChina Foreign Language14(11), 753762. DOI:10.17265/15398080/2016.11.001. Retrieved from https://www.researchgate.net/publication 1311522177_Pragmatic_and_Semantic_

Potential_of_Newspaper_Headlines

Le, E. (2012). Gateways to the news: Headlines on Le Monde's home page and front page. Discourse, Context \& Media, 1(1), 32-44.

Mårdh, I. (1980). Headlinese: On the grammar of English front page headlines. (Vol. 58). Lund: Liberläromedel/Gleerup.

Metz, J. L. (2005). Babes, balls, and babies: A working ethnography of motherhood (An Unpublished Doctoral Dissertation). University of Illinois at Urbana-Champaign.

Mey, J. L. (2001). Pragmatics: An introduction. Oxford: International Journal of English and Education.

Qomariyah, A. N. (2019). A pragmatic study of Jakarta Post and Jakarta Globe new headlines after Indonesian general election 2019. International Journal of 
Humanities, Arts and Social Sciences, 5(4), 128-137.

Quirk, R. (2010). A comprehensive grammar of the English language. India: Pearson Education India.

Quirk, R. Greenbaum, S.; Leech, G. \& Svartvik, J. (2010). A comprehensive grammar of the English language. India: Pearson Education India.

Reah, D. (2002). The language of newspapers. New York: Psychology Press.

Rustam, R. (2013). Pragmatic Analysis of CNN Headlines Representing Pakistan (An Unpublished Doctoral Dissertation). University of Azad Jammu and Kashmir, Muzaffarabad, Pakistan.

Searle, J. R. (1965). What is a speech act? Perspectives in the philosophy of language: A concise anthology 2000. Oxford: Oxford University Press.

Searle, J. R. (1968). Austin on locutionary and illocutionary acts. The philosophical review, 77(4), 405-424.

Searle, J. R. (1975). A taxonomy of illocutionary acts. Minneapolis: University of Minnesota Press.

Searle, J. R. (1979). What is an intentional state? Mind, 88(349), 74-92.

Seiter, Courtney (2014). 8 winning headline strategies and the psychology behind them. Retrieved from https://buffer.com/resources/headlinestrategies-psychology/

Shams, M. A. (2002). Practice with Newspapers. Iran. Entesharat Jangle.

Swan, M. (2005). Practical English usage. Oxford: Oxford University Press.

Taiwo, R. (2007). Language, ideology and power relations in Nigerian newspaper headlines. Nebula, 4(1). Retrieved from https://www.researchgate.net/publication/264 56692_Language_Ideology_and_Power_Rel ations_in_Nigerian_Newspaper_Headlines

Van Dijk, T. A. (1988). News as discourse. Hillsdale: Lawrence Erlbaum Associates Publishers.
Waugh, L. R. (1995). Reported speech in journalistic discourse: The relation of function and text. Text-Interdisciplinary Journal for the Study of Discourse, 15(1), 129-173.

Wierzbicka, A. (1992). Semantics, culture, and cognition: Universal human concepts in culture-specific configurations. Oxford: Oxford University Press.

Yoshimi, T. (2001). Improvement of translation quality of English newspaper headlines by automatic pre-editing. Machine translation, 16(4), 233-250. 